\title{
Multilevel Analysis of the Pressure of Agricultural Land Conversion, Degree of Urbanization and Agricultural Land Prices in Taiwan
}

\author{
Chun-Chang Lee ${ }^{1}$, Yi-Xin Chen ${ }^{1}$, Yun-Ling Wu ${ }^{1, *}$, Wen-Chih Yeh ${ }^{2}$ and Chih-Min Liang ${ }^{3}$ \\ 1 Department of Real Estate Management, National Pingtung University, Pingtung 90004, Taiwan; \\ lcc@mail.nptu.edu.tw (C.-C.L.); bae107206@nptu.edu.tw (Y.-X.C.) \\ 2 Department of Real Estate Management, HungKuo Delin University of Technology, \\ New Taipei City 23654, Taiwan; wen00126@mail.hdut.edu.tw \\ 3 Department of Public Finance and Tax Administration, National Taipei University of Business, \\ Taipei City 10478, Taiwan; cmliang@ntub.edu.tw \\ * Correspondence: annya@mail.nptu.edu.tw; Tel.: +886-8-7663800 (ext. 32660)
}

Received: 18 October 2020; Accepted: 17 November 2020; Published: 25 November 2020

\begin{abstract}
In 2000, to efficiently implement land-use policies, the Taiwanese government amended the Agricultural Development Act by easing restrictions on agricultural land purchases. As a result of increasing land development and investment needs, agricultural land prices have surged. This study aims to examine whether agricultural land prices in Pingtung County are affected by land control policy measures, the pressure of agricultural land conversion and the degree of urbanization. A multilevel analysis approach was used to analyze land price differences in townships in Pingtung County. The estimation results derived from the null model indicated significant differences between the mean land price in each administrative division. Specifically, the ratio of agricultural land prices affected by differences in Level 2 township-related factors was $21.8 \%$, while the ratio of those affected by differences in Level 1 land-related factors was 78.2\%. An empirical intercepts-and-slopes-as-outcomes regression model demonstrated that Level 2 township-related factors, such as the pressure of agricultural land conversion and the degree of urbanization, had cross-level, direct and positive impacts on agricultural land prices; while Level 1 land-related factors, such as lot size control measures on farmhouse construction and land-use zoning, had positive and significant impacts on agricultural land prices.
\end{abstract}

Keywords: land control policy; pressure of agricultural land conversion; degree of urbanization; agricultural land prices; multilevel analysis

\section{Introduction}

Within Taiwan's existing land-use policies, the Urban Planning Law and Regional Plan Act are the primary pieces of legislation regulating land-use zoning. In addition to these, the Spatial Planning Act announced in 2016 requires local governments to tailor land-use zoning to suit local conditions, while the Agricultural Development Act is the main act regulating agricultural lands. In 2000, following changes to Taiwan's economic structure, the government amended the Agricultural Development Act by allowing natural persons to freely purchase or sell agricultural land. The easing of this restriction has changed the conditions under which legal persons engaging in agribusiness may purchase agricultural land. Specifically, the legislative definition of agricultural land ownership was amended from "those who farm agricultural land own the land" to "agricultural land should only be used for agricultural purposes." Natural persons are also allowed to build individual or collective farmhouses, under the condition that such constructions will not have negative impacts on 
the agricultural production environment or the development of farming communities. As a result, land developments require large investments in the agricultural land market. Lin [1] claimed that agricultural land transactions in urban fringes are a leading indicator of agricultural land conversion. Such transactions gradually reduce the size of agricultural lands while increasing nonagricultural usage, thereby increasing prices as well as the need to engage in agricultural land transactions.

Chicoine [2] asserted that the convergence of agricultural and urban forces at the urban fringe affects the value of agricultural land ownership and, consequently, land prices. Kuo [3] stated that converted agricultural lands are often located on plains or are desirable locations for nonagricultural purposes such as residential, commercial and industrial buildings, and public infrastructure. This produces the anticipatory effects of increasing agricultural land prices, which results in speculation. As agricultural land can be used to build farmhouses for residential purposes as well as for trading, it has become a product of speculative investment, which leads to land conversion and surging land prices $[1,4,5]$. Moreover, agricultural land prices are associated with the degree of urbanization in the area [6-8].

Concerning lot-size restrictions on farmhouse construction on agricultural land, Article 16 of the Agricultural Development Act stipulates that arable land shall not be divided if each divided lot size is less than 0.25 hectares. Furthermore, Article 2 of the Regulations on the Construction of Farmhouses on Agricultural Lands requires a constructed farmhouse to have a lot size no smaller than 0.25 hectares. Such regulations prevent an excess of agricultural land owners and limit the amount of divided land being used for nonfarming purposes. Therefore, the changes in the value of agricultural land resulting from the formulation of land use policies have contributed to increasing agricultural land prices.

Many relevant studies have employed the hedonic price theory to examine the factors affecting real estate prices. Hox [9] pointed out that analyzing different levels of characteristics variables at a single level leads to the emergence of fallacies in statistical inference. In contrast to the problem of hasty generalization, ecological fallacy occurs when inferences about the nature of individuals are deduced from inferences about the group. Giuliano, Gordon, Pan, and Park [10] suggested that multilevel modeling, also known as hierarchical linear modeling (HLM), allows for the control of research data due to the variances that arise from regional differences. To date, very few studies have employed multilevel models to analyze and estimate agricultural land prices [11]. This study considered several factors such as land characteristics (lot-size restrictions on farmhouse construction; land-use zoning; and regulation) and locational characteristics to produce a hierarchical linear model and analysis on whether agricultural land prices in Pingtung County in Taiwan vary by township, as well as whether differences exist between the impacts caused by the pressure of land conversion and degree of urbanization. The objectives of this study were three-fold: (1) To examine whether differences exist between the influences of different townships on agricultural land prices; (2) To examine the effects of land characteristics (lot size of constructed farmhouse, land-use zoning, distance from a land to a railway station, year of transaction) on agricultural land prices; and (3) To examine whether township characteristics (pressure of agricultural land conversion, degree of urbanization) have cross-level and direct effects on agricultural land prices, in the context of land prices being influenced by the Level 1 independent variables.

\section{Literature Review}

Most studies that examined the factors affecting agricultural land prices did so from the perspective of agricultural land productivity. For instance, Patton and McErlean [12] focused on agricultural factors related to the capability of an agricultural land to produce crops, such as soil fertility classification. In considering the factors that influence land prices, Tsoodle, Golden and Featherstone [13] categorized the components of land price into production, consumption, speculation and transaction. The speculative component is derived from market-participant expectations. Buyers expect land prices to follow a certain trend over time, regardless of whether the trend is negative or positive. Developers in particular may expect to have land converted to other uses than agriculture. Lehn and Bahrs [14] divided the factors that affect agricultural land prices into four categories: 
land factors (average slope, soil quality); farm factors (farm size, livestock density); environmental policy-related factors (ratio of protected lot size to total lot size, density of wind turbines); and urban sprawl (population density, distance to nearest urban area). The results show that the factors influencing agricultural land prices are not limited to land factors, but include neighborhood and locational factors such as the population in an urban or rural area and the accessibility of a location.

A review of relevant studies on the factors influencing agricultural land prices suggests that most factors can be grouped into two major categories: land value and location. Factors pertaining to land value include lot size $[1,7,15-17]$, land quality [18-20] and agricultural land characteristics $[7,20,21]$. Factors relating to land location include the accessibility of a land from a road [22,23], the distance from a farmland to the nearest city $[16,17,24]$ and the degree of urbanization $[7,8]$.

Pope III and Goodwin Jr [6] suggested that the factors affecting agricultural land price include income level, population level, location of urbanized areas and location characteristics. Similarly, Borchers, Ifft and Kuethe [25] claimed that the factors governing agricultural land prices can be classified into population and urban influence (population density, time to commute to urban area, etc.), recreational and natural factors (tree cover, availability of hunting licenses, etc.) and locational characteristics (distance to nearest hospital, distance to nearest golf course, etc.).

Nelson and Schumaker [26], along with Umanailo, Nawawi, Umanailo, Malik and Hentihu [27], used the hedonic price approach based on the pressure of agricultural land conversion to analyze the factors influencing agricultural land prices. Livanis et al. [28] asserted that the pressure of agricultural land conversion and speculative demands are the most salient factors affecting agricultural land prices in the Northeastern region of the United States. Lin [1] examined the surge in agricultural land prices stemming from the anticipatory psychological effects of land-use conversion in Taiwan. The results indicate that if an agricultural land is expected to be designated for urban development, the potential benefits of land conversion could skew the original land-price mechanism. Due to its location in development areas, the population density or economic indicators of an urban fringe are often incentives for conversion, which positively influences land price [29]. Agricultural land prices are substantially affected by urban sprawl. Under the influence of capitalism, potential land developments will elevate land prices [30]. Huang [31] studied the influence of socioeconomic developments (such as degree of urbanization) and agricultural developments (such as agricultural land density and value) on agricultural land prices. Peerzado, Magsi and Sheikh [32] asserted that Pakistan's Qasimabad subdivision was the subdivision most affected by the $44 \%$ growth in population in Hyderabad, as the streets of Qasimabad had become urbanized. Moreover, 70\% of agricultural land in Hyderabad had been converted for urban development purposes, which led to changes in land-use demands. These studies demonstrate that the pressure of agricultural land conversion and degree of urbanization are salient factors affecting agricultural land prices.

Some scholars have focused on other factors affecting agricultural land prices. Tsoodle, Golden and Featherstone [13] investigated the effects of personal relationships and social capital on agricultural land prices in Kansas. They argued that multitude of factors, such as lot size, type of road access, rainfall, type of agricultural land use, tax policies, land capitalization rate, urgent selling or special relations and capital restrictions, affect agricultural land transaction prices and vary depending on the year of transaction. Lee [33] analyzed the influence of natural landscapes and farmhouse construction control policies on agricultural land prices. The results indicated that in addition to the significant impact of natural landscapes, lot size restrictions on farmhouse construction and competition from homestay operators also affect agricultural land prices. Table 1 lists studies that have explored factors that influence agricultural land prices and categorizes them according to their focus, i.e., agricultural land productivity, land value and location, population level, location of urbanized areas and location characteristics, pressure of agricultural land conversion and other factors. 
Table 1. List of studies that have explored factors influencing agricultural land prices.

\begin{tabular}{ccc}
\hline Author (age) & Range of Study & Note \\
\hline Patton and McErlean (2003) & $\begin{array}{c}\text { This study focused on agricultural factors related to the ability } \\
\text { of a segment of agricultural land to produce crops, such as soil } \\
\text { fertility classification. }\end{array}$ \\
\hline $\begin{array}{c}\text { Tsoodle, Golden and } \\
\text { Featherstone (2006) }\end{array}$ & $\begin{array}{c}\text { This study categorized the components of land price into } \\
\text { production, consumption, speculation and transaction. The } \\
\text { speculative component is derived from market-participant } \\
\text { expectations. Buyers expect land prices to follow a certain } \\
\text { trend over time, regardless of whether the trend is negative or } \\
\text { positive. Developers in particular may expect to have land } \\
\text { converted for uses other than agriculture. }\end{array}$ \\
$\begin{array}{c}\text { This study divided the factors that affect agricultural land } \\
\text { prices into four categories: land factors (average slope, soil } \\
\text { quality); farm factors (farm size, livestock density); } \\
\text { [13] } \\
\text { environmental policy-related factors (ratio of protected lot size } \\
\text { to total lot size, density of wind turbines); and urban sprawl } \\
\text { (population density, distance to nearest urban area). The } \\
\text { results show that the factors influencing agricultural land } \\
\text { prices are not limited to land factors, but include }\end{array}$ \\
neighborhood and locational factors such as the population in \\
an urban or rural area and the accessibility of a location.
\end{tabular}

\section{Land value and location}

Chicoine (1981); Gardner and Barrows (1985); Huang et al. (2006); Maddison (2000; 2009)

Palmquist and Danielson (1989); Faux and Perry (1999); Xu et al. (1993).

Donoso and Vicente (2001); Huang et al. (2006); Troncoso et al. (2010)

Nivens et al., 2002;

Troncoso et al., 2010

Maddison (2000; 2009)

Sklenicka et al. (2013)

Huang et al. (2006); Taylor and Brester (2005)
Agricultural land is strongly influenced by natural factors such as climate, soil quality and altitude. With regard to agricultural land prices, the distance of agricultural land from cities and towns is an influencing factor, and differences in price can be determined using different locations and values.

As agricultural land plots differ in terms of their fertility and the attractiveness of their location, their land rents, and consequently, prices, also differ. From the perspective of agricultural production, the primary factors affecting agricultural income include agricultural fertility, agricultural income and the availability of irrigation facilities.

In regard to the influence of agricultural land characteristics on agricultural land prices, the primary influencing characteristics are land area, soil quality, water rights, connectivity, location, agricultural land productivity and distance to cities.

Agricultural land prices are affected by proximity to urban areas; highways contribute to rising agricultural land prices as they improve the accessibility of agricultural areas. Furthermore, agricultural land plots located closer to urban areas not only benefit from transportation cost savings, but are also better positioned to change their agricultural cost structure or convert to forms of agricultural production that offer higher value.

Compared to other areas that are located further away from cities, the areas that are located closer to urban settlements and connected to efficient transportation networks are priced significantly higher. This is a reflection of the influence that location and proximity to cities have on agricultural land

$$
\text { prices. }
$$

Both production and nonproduction factors influence agricultural land prices, which change over time and space.

Empirical analyses revealed nine factors that influence agricultural land prices in Illinois, USA, with agricultural productivity, population density, and agricultural income being significantly and positively correlated to agricultural land prices. 
Table 1. Cont.

\begin{tabular}{|c|c|c|}
\hline Author (age) & Range of Study & Note \\
\hline \multicolumn{3}{|c|}{ 3. Level, population level, location of urbanized areas and location characteristics } \\
\hline Pope III and Goodwin Jr (1984) & $\begin{array}{c}\text { This study suggested that the factors affecting agricultural } \\
\text { land price include income level, population level, location of } \\
\text { urbanized areas and location characteristics. }\end{array}$ & [6] \\
\hline Borchers, Ifft, and Kuethe (2014) & $\begin{array}{l}\text { This study claimed that the factors governing agricultural land } \\
\text { prices can be classified into population and urban influence } \\
\text { (population density, time to commute to urban area, etc.); } \\
\text { recreational and natural factors (tree cover, availability of } \\
\text { hunting licenses, etc.); and locational characteristics (distance } \\
\text { to nearest hospital, distance to nearest golf course, etc.). }\end{array}$ & {$[25]$} \\
\hline \multicolumn{3}{|c|}{ 4. Pressure of agricultural land conversion } \\
\hline $\begin{array}{l}\text { Nelson and Schumaker (2001); } \\
\text { Umanailo, Nawawi, Umanailo, } \\
\text { Malik and Hentihu (2019) }\end{array}$ & $\begin{array}{l}\text { This study used the hedonic price approach based on the } \\
\text { pressure of agricultural land conversion to analyze the factors } \\
\text { influencing agricultural land prices. }\end{array}$ & {$[26,27]$} \\
\hline Livanis et al. (2006) & $\begin{array}{c}\text { This study asserted that the pressure of agricultural land } \\
\text { conversion and speculative demands are the most salient } \\
\text { factors affecting agricultural land prices in the Northeastern } \\
\text { region of the United States. }\end{array}$ & {$[28]$} \\
\hline Lin $(2007)$ & $\begin{array}{c}\text { This study examined the surge in agricultural land prices } \\
\text { stemming from the anticipatory psychological effects of } \\
\text { land-use conversion in Taiwan. }\end{array}$ & [1] \\
\hline $\begin{array}{l}\text { Delbecq, Kuethe and } \\
\text { Borchers (2014) }\end{array}$ & $\begin{array}{c}\text { The results of this study indicate that if an agricultural land is } \\
\text { expected to be designated for urban development, the } \\
\text { potential benefits of land conversion could skew the original } \\
\text { land-price mechanism. Due to its location in development } \\
\text { areas, the population density or economic indicators of an } \\
\text { urban fringe are often incentives for conversion, which } \\
\text { positively influences land price }\end{array}$ & [29] \\
\hline Drescher et al. (2001) & $\begin{array}{l}\text { Agricultural land prices were found to be substantially } \\
\text { affected by urban sprawl. Under the influence of capitalism, } \\
\text { potential land development projects will elevate land prices }\end{array}$ & [20] \\
\hline Huang (2012) & $\begin{array}{l}\text { This study examined the influence of socioeconomic } \\
\text { developments (such as degree of urbanization) and } \\
\text { agricultural developments (such as agricultural land density } \\
\text { and value) on agricultural land prices. }\end{array}$ & {$[31]$} \\
\hline Peerzado, Magsi and Sheikh (2019) & $\begin{array}{l}\text { This study asserted that Pakistan's Qasimabad subdivision } \\
\text { was the subdivision most affected by the } 44 \% \text { growth in } \\
\text { population in Hyderabad, as the streets of Qasimabad had } \\
\text { become urbanized. Moreover, } 70 \% \text { of agricultural land in } \\
\text { Hyderabad had been converted for urban development } \\
\text { purposes, which led to changes in land-use demands. These } \\
\text { studies demonstrate that the pressure of agricultural land } \\
\text { conversion and degree of urbanization are salient factors } \\
\text { affecting agricultural land prices. }\end{array}$ & [32] \\
\hline \multicolumn{3}{|c|}{ 5. The other factors affecting agricultural land prices } \\
\hline $\begin{array}{l}\text { Tsoodle, Golden and } \\
\text { Featherstone (2006) }\end{array}$ & $\begin{array}{l}\text { This study investigated the effects of personal relationships } \\
\text { and social capital on agricultural land prices in Kansas. They } \\
\text { argued that a multitude of factors, such as lot size, type of road } \\
\text { access, rainfall, type of agricultural land use, tax policies, land } \\
\text { capitalization rate, urgent selling or special relations and } \\
\text { capital restrictions, affect agricultural land transaction prices } \\
\text { and vary depending on the year of transaction. }\end{array}$ & [13] \\
\hline Lee (2015) & $\begin{array}{l}\text { This study analyzed the influence of natural landscapes and } \\
\text { farmhouse construction control policies on agricultural land } \\
\text { prices. The results indicate that in addition to the significant } \\
\text { impact of natural landscapes, lot size restrictions on } \\
\text { farmhouse construction and competition from homestay } \\
\text { operators also affect agricultural land prices. }\end{array}$ & [33] \\
\hline
\end{tabular}

Past studies have mostly used the hedonic price model to explore factors that influence land prices [34-37]. Their approach involves the use of a single-level linear regression model to examine 
factors that influence land prices. However, to a certain extent, information pertaining to social attributes form a nested structure [38]. In a single-level model, it is assumed that all relevant variations occur at a single level over the course of changes to time and space. When inferring only through a single-level structure, it is easy to make the mistake of misusing theory and making out-of-focus inferences, resulting in an erroneous understanding of practical phenomena [39]. Antipova, Wang and Wilmot [40] suggested that when individuals are nested within a region, those within the same region are similar. Hence, the authors employed the multilevel modeling approach, also known as the hierarchical linear modeling (HLM) approach, for analysis. The first level consists of spatial attributes such as land use type and distance to higher education institutions nearby, as well as individual attributes such as income and gender. The second level consists of neighborhood sociodemographic attributes. The empirical results demonstrate that land use type can account for commuting time, while the sociodemographic attributes of individuals and neighboring areas have noticeable effects on commuting time. According to Hofmann [41], HLM not only takes into account the features of different levels and prevents bias resulting from conventional hedonic price estimations, but also treats the residuals of different levels at the same time, as well as measuring the effects of individual-level variables and aggregate-level variables on outcome variables. Therefore, HLM is able to calculate the explained variance of cross-level variables on individual-level outcome variables. Giuliano, Gordon, Pan and Park [10] suggested that multilevel modeling allows one to control the research data due to the variances that arise from regional differences.

Brown and Uyar [42] used a hierarchical linear model to examine the influence of residential building characteristics and neighborhood characteristics on residential housing prices, incorporating area into building characteristics (individual level) and commuting distance into neighborhood characteristics (overall level). The empirical results of that study indicated that neighborhood characteristics significantly influence residential housing prices and can mediate the influence of individual building characteristics on residential housing prices. That is to say that the longer the commuting time, the lower the residential housing price, and that the shorter the commuting time, the greater the effect of each additional unit of land area. This study emphasized the use of hierarchical linear models as a means of avoiding of errors such as estimation and inference errors. Lee and Ton [39] used building characteristics (i.e., house age, area, structure, form and purpose) as individual level variables and regional characteristics (i.e., population density, education level and disposable income) as overall level variables. The empirical results showed that at the individual level, house age, area, structure, form and purpose all significantly influence residential housing prices, and that the overall level, disposable income significantly influences the average residential housing prices of each county (city). The influence of building characteristics on residential housing prices differed among county (city) regions. Regional characteristics directly affect residential housing prices and have a mediating effect on the relationship between building characteristics and residential housing prices. The influence of building characteristics on residential housing prices differed among county (city) regions. Regional characteristics directly affect residential housing prices and have a regulatory effect on the relationship between building characteristics and residential housing prices. They then compared their results with those obtained using a traditional hedonic price model, and found that the hedonic price model underestimated standard errors of regression coefficients and enlarged type I errors, as it had ignored important variables.

The present study examined the factors that influence agricultural land prices in Taiwan. The variables in the hedonic land value model developed by Tsoodle, Golden and Featherstone [13] were used as references to perform an empirical analysis through HLM. Level 1 consists of land-related factors, such as land regulations, lot size, lot size of a constructed farmhouse, land-use zoning and control measures, the distance from the land to the railway station of each administrative division (or the nearest railway station) and the year of land transaction. Level 2 consists of factors pertaining to the characteristics of administrative divisions, such as the pressure of agricultural land conversion and degree of urbanization. 


\section{Empirical Model Settings}

In this study, the Level 1 variables consist of land-related characteristics, and the Level 2 variables consist of administrative division-related characteristics. First, a null model was set up, followed by an intercepts-and-slopes-as-outcomes regression model. The settings of the variables are detailed in Table 2.

Table 2. Description of variables.

\begin{tabular}{|c|c|c|c|}
\hline $\begin{array}{l}\text { Level and Type } \\
\text { of Variable }\end{array}$ & Variable & Definition & $\begin{array}{l}\text { Expected } \\
\text { Signs }\end{array}$ \\
\hline Dependent variable & $\begin{array}{l}\text { Agricultural land } \\
\text { price } \\
\ln (\text { Price })\end{array}$ & $\begin{array}{l}\text { The logarithmic form of an agricultural land-only transaction } \\
\text { price logged in the national transaction price registration } \\
\text { system was used for estimation. The units are in NT\$. }\end{array}$ & \\
\hline \multirow{4}{*}{$\begin{array}{c}\text { Level } 1 \\
\text { independent variable }\end{array}$} & $\begin{array}{l}\text { Lot size control } \\
\text { measures } \\
(\text { Control })\end{array}$ & $\begin{array}{l}\text { Article } 18 \text { of the Agricultural Development Act stipulates that } \\
\text { a farmhouse can only be erected on an agricultural land plot } \\
\text { with a minimum size of } 0.25 \text { hectares }\left(2500 \mathrm{~m}^{2}\right) \text {. A dummy } \\
\text { variable, with land plots smaller than } 0.25 \text { hectares served as } \\
\text { the reference group. For the CONTROL variable, land plots } \\
\text { larger than } 0.25 \text { hectares were given a score of } 1 \text {, while land } \\
\text { plots smaller than } 0.25 \text { hectares were given a score of } 0 \text {. } \\
\text { The symbol was expected to be positive. }\end{array}$ & + \\
\hline & $\begin{array}{l}\text { Land use zoning } \\
\text { (Urbanf and Conspf) }\end{array}$ & $\begin{array}{l}\text { Three land zones were established according to the Urban } \\
\text { Planning Law, the Regional Plan Act and the Regulations on } \\
\text { Non-Urban Land Use Control: urban agricultural zones, } \\
\text { nonurban special agricultural zones and nonurban general } \\
\text { agricultural zones. Nonurban general agricultural zones were } \\
\text { used as a reference group and two dummy variables were } \\
\text { specified. For the Urbanf variable, urban agricultural zones } \\
\text { were specified as 1, while the other two zones were specified } \\
\text { as } 0 \text {. For the Conspf variable, nonurban special agricultural } \\
\text { zones were specified as 1, while the other two zones were } \\
\text { specified as 0. The symbol was expected to be positive } \\
\text { or negative. }\end{array}$ & $+1-$ \\
\hline & $\begin{array}{l}\text { Distance to railway } \\
\text { station } \\
\text { (lnDistrain) }\end{array}$ & $\begin{array}{l}\text { A continuous variable in which the logarithmic form of the } \\
\text { distance from a plot of agricultural land to the railway station } \\
\text { of each administrative division in Pingtung County. The units } \\
\text { are in meters. The symbol was expected to be negative. }\end{array}$ & - \\
\hline & $\begin{array}{l}\text { Year of transaction } \\
\text { (D1 D6) }\end{array}$ & $\begin{array}{l}\text { This study utilized data ranging from } 2012 \text { to } 2018 \text {, with the } \\
\text { year } 2012 \text { serving as the reference group and six dummy } \\
\text { variables specified. D1 represents agricultural land } \\
\text { transactions in the year 2013, specified as 1, while land } \\
\text { transactions in other years were specified as 0. D2 represents } \\
\text { agricultural land transactions in the year 2014, specified as 1, } \\
\text { while land transactions in other years were specified as 0. D3 } \\
\text { represents agricultural land transactions in the year 2015, } \\
\text { specified as 1, while land transactions in other years were } \\
\text { specified as 0. D4 represents agricultural land transactions in } \\
\text { the year 2016, specified as 1, while land transactions in other } \\
\text { years were specified as 0. D5 represents agricultural land } \\
\text { transactions in the year } 2017 \text {, specified as } 1 \text {, while land } \\
\text { transactions in other years were specified as 0. D6 represents } \\
\text { agricultural land transactions in the year 2018, specified as } 1 \text {, } \\
\text { while land transactions in other years were specified as } 0 . \\
\text { The symbol was expected to be positive or negative. }\end{array}$ & $+/-$ \\
\hline \multirow{2}{*}{$\begin{array}{c}\text { Level } 2 \\
\text { independent variables }\end{array}$} & $\begin{array}{c}\text { Pressure of } \\
\text { agricultural land } \\
\text { conversion (lnPress) }\end{array}$ & $\begin{array}{l}\text { The pressure of agricultural land conversion was calculated as } \\
\text { follows: Pressure of agricultural land conversion index }= \\
\text { (mean population of an administrative division divided by the } \\
\text { agricultural land size of the division) } * 100 \% \text {, the logarithmic } \\
\text { form is taken. In other words, when this value is large, so is } \\
\text { the pressure of agricultural land conversion. The symbol was } \\
\text { expected to be positive. }\end{array}$ & + \\
\hline & $\begin{array}{l}\text { Degree of } \\
\text { urbanization } \\
\text { (lnUrbanization) }\end{array}$ & $\begin{array}{l}\text { The degree of urbanization is calculated as follows: } \\
\text { Population per unit land size (mean population of an } \\
\text { administrative division divided by the land size of the } \\
\text { division in hectares). The logarithmic form is taken. } \\
\text { The larger the value, the higher the degree of urbanization. } \\
\text { The symbol was expected to be positive. }\end{array}$ & + \\
\hline
\end{tabular}




\subsection{Null Model}

In a null model, no independent variables are placed in the first and second levels. To validate the presence of differences between groups, as well as the contribution of between-group variance to the total variance, the test results of the null model were used as a preliminary assessment of the choice between HLM or traditional regression analysis [43]. The goal of the null model was to measure the degree of variance between different levels at a mean agricultural land price, that is, to divide the variance into different levels to establish whether differences exist between the variation of each level, as well as the mean of the dependent variables in each level. The settings of the null model are shown in Equations (1) and (2):

$$
\begin{aligned}
& \text { Level } 1: \text { InPrice }_{i j}=\beta_{0 j}+\varepsilon_{i j}, \varepsilon_{i j} \sim N\left(0, \sigma^{2}\right) \\
& \text { Level } 2: \beta_{0 j}=\gamma_{00}+\mu_{0 j}, \mu_{0 j} \sim N\left(0, \tau_{00}\right)
\end{aligned}
$$

Substituting Equation (2) into Equation (1) yields the following mixed model:

$$
\text { Mixed : } \ln _{\text {Price }} i j=\beta_{0 j}+\gamma_{00}+\mu_{0 j}+\varepsilon_{i j}
$$

$i=$ land transaction code number of each administrative division, i.e., each piece of land transaction data. $j=$ code number of each administrative division.

InPrice $_{i j}=$ Natural logarithm of the $i$ th agricultural land transaction price of the $j$ th administrative division.

$\beta_{0 j}=$ Mean agricultural land price of the $j$ th administrative division.

$\varepsilon_{i j}=$ Error term of the mean agricultural land price if the $j$ th administrative division; assume that the mean is 0 , the variance is $\sigma^{2}$, and the error term is independently and identically distributed.

$\gamma_{00}=$ Grand mean agricultural land price of each administrative division.

$\mu_{0 j}=$ Difference between the mean agricultural land price of each administrative division and the grand mean agricultural land price of all administrative divisions.

$\tau_{00}=$ Variance of $\mu_{0 j}$ (between-group variance).

In this study, there were 26 administrative divisions in the sample size $(j=26) . \mu_{0 j}$ represents the difference in the grand mean agricultural land price of each administrative division. Hence, Equations (1) to (3) consist of 26 regression equations for predicting agricultural land prices, with each equation corresponding to each administrative division. This is to validate the presence of differences between the mean agricultural land price in each administrative division. When the random component of the difference between groups $\left(\mu_{0 j}\right)$ is validated and shown to have attained a level of significance, then the mean agricultural land price in each administrative division is considered to be different.

In the null model, $\operatorname{var}\left(\right.$ InPrice $\left._{i j}\right)=\operatorname{var}\left(\mu_{0 j}+\varepsilon_{i j}\right)=\tau_{00}+\sigma^{2}$. Here, let $\rho=\tau_{00} /\left(\tau_{00}+\sigma^{2}\right)$, where $\rho$ is the intraclass correlation coefficient (ICC), also known as the cluster effect [44]. McGraw and Wong [45] stated that an ICC can be used to explain the proportion of between-group variance in the overall variance. An ICC represents the degree to which the variance of a dependent variable can be explained by the between-group difference. In summary, the null model is used to test whether the difference in the mean agricultural land price in each administrative division has attained statistical significance. Moreover, the degree of variance in the total variance of a land price is a result of the price difference between the administrative divisions.

\subsection{Intercepts-And-Slopes-As-Outcomes Regression Model}

The dependent variable in this study was the logarithm of an agricultural land price. The Level 1 independent variables were restrictions on farmhouse lot size and agricultural land use types, which were divided into urban agricultural zones, nonurban special agricultural zones and nonurban 
general agricultural zones, with the latter two groups serving as a reference group. Two dummy variables, Urbanf and Conspf, were set; the logarithm of the distance from an agricultural land to a railway station was set as $\ln$ Distrain, along with six dummy variables pertaining to the year of transaction (D1 D6). The characteristic variables in the second level included the pressure of agricultural land conversion (lnPress) and degree of urbanization (lnUrbanization). The definitions of the variables are listed in Table 2. An intercepts-and-slopes-as-outcomes regression model was developed, in which the Level 1 intercepts served as outcome variables, and the independent variables were substituted into the second level. Level 1 (individual) explanatory variables were treated by group-mean-centering, so as to convey the grand mean on the intercept $\gamma_{00}$ Level 2 (aggregate) explanatory variables were treated by grand-mean-centering; $\beta_{0 j}$ can be transformed into the group mean of the dependent variables, while $u_{0 j}$ is the difference between the group mean and the grand mean $\gamma_{00}$. Here, $\tau_{00}$ is the variance of the group mean, which has explanatory significance. The coefficients of the Level 1 independent variables were modeled as random effects, with the exception of the coefficients of the dumm variables of the years of transaction (D1 D6), which were modeled as fixed effects. The intercepts were also modeled as random effects. The model was set up as shown below:

Level 1

$$
\begin{aligned}
& \text { InPrice }_{i j}=\beta_{0 j}+\beta_{1 j}\left(\text { Control }_{1 j}-\overline{\text { Control }_{. j}}\right)+\beta_{2 j}\left(\text { Urbanf }_{2 j}-\overline{\text { Urbanf }_{. j}}\right) \\
& +\beta_{3 j}\left(\text { Conspf }_{3 j}-\overline{\text { Conspf }_{. j}}\right)+\beta_{4 j}\left(\text { InDistrain }_{4 j}-\overline{\operatorname{lnDistrain}_{. j}}\right)+\sum_{k=1}^{6} \delta_{k} D_{k}+\varepsilon_{i j}, \varepsilon_{i j} \sim N\left(0, \sigma^{2}\right)
\end{aligned}
$$

Level 2

$$
\begin{gathered}
\beta_{0 j}=\gamma_{00}+\gamma_{01}\left(\ln _{\text {Pr ice }}-\overline{\ln \text { Price }}\right)+\gamma_{02}\left(\text { InUrbanization }_{i j}-\ln \overline{\text { Urbanization }}\right) \\
+\mu_{0 j}, \mu_{0 j} \sim N\left(0, \tau_{00}\right) \\
\beta_{i j}=\gamma_{i 0}+\mu_{i j}, \mu_{i j} \sim N\left(0, \tau_{i i}\right), i=1, \ldots, 4 \\
\delta_{k}=\gamma_{4+k 4+k}, k=1, \ldots, 6
\end{gathered}
$$

Control $_{1 j}-\overline{\text { Control }_{. j}}$ : A dummy variable that represents farmhouse lot-size control measures translated to the group mean; this variable is treated by means of centering.

Urbanf $_{2 j}-\overline{\text { Urbanf }}$. : : A dummy variable that represents urban agricultural zones translated to the group mean; this variable is treated by means of centering.

Consp $f_{3 j}-\overline{\text { Conspf. }}$ : A dummy variable that represents nonurban special agricultural zones translated to the group mean; this variable is treated by means of centering.

$\operatorname{lnDistrain}_{4 j}-\overline{\ln \text { Distrain }_{. j}}$ : A continuous variable that represents the logarithmic form of the distance between an agricultural land and the railway station of each administrative division (or the nearest railway station)

$D_{k}$ : Transaction data from 2012 to 2018, with the year 2012 as a reference group. Six dummy variables, $D_{1}, \ldots, D_{6}$, were specified.

$\varepsilon_{i j}$ : Random error term. Assume that the mean is 0 , the variance is $\sigma^{2}$, and the error term is independently and identically distributed.

$\beta_{0 j}$ : Level 1 intercept; $\beta_{1 j}, \ldots \ldots, \beta_{4 j}$ is the coefficient of each Level 1 independent variable.

$\delta_{k}$ : Coefficient of the dummy variable of the year of transaction (D1 D6).

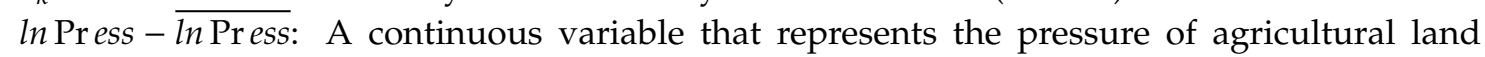
conversion translated tothe grand mean. InUrbanization- $\overline{\ln U r b a n i z a t i o n}$ : A continuous variable that represents the degree of urbanization translated to the grand mean.

$\gamma_{00}$ is the grand mean agricultural land price of all administrative divisions; $\gamma_{01}$ is the influence of the Level 2 variable of the pressure of agricultural land conversion on the mean agricultural land price of each administrative division; $\gamma_{02}$ is the influence of the Level 2 variable of the degree of urbanization 
on the mean agricultural land price of each administrative division. $\beta_{i j}$ is the coefficient of the Level 1 independent variables, modeled as random effects.

Centering can be used to prevent collinearity in HLM $[43,46]$. In Equation (5) the mean agricultural land price $\left(\beta_{0 j}\right)$ of each administrative division was regarded as an outcome variable and added to the Level 2 independent variable ( $\ln$ Press $-\overline{\ln \text { Press, }}$ lnUrbanization-InUrbanization $)$, so as to validate whether the Level 2 independent variables had influenced the mean agricultural land price of each administrative division. Substituting Equations (5) to (7) into Equation (4) yields the intercepts-and-slopes-as-outcomes regression model shown in Equation (8):

$$
\begin{aligned}
& \ln \text { Pr ice }_{i j}=\gamma_{00}+\gamma_{01}\left(\text { lnPrice }_{i j}-\overline{\ln \text { Price }}\right)+\gamma_{02}\left(\operatorname{lnUrbanization}_{i j}-\ln \overline{\text { Urbanization }}\right) \\
& +\gamma_{10}\left(\text { Control }_{1 j}-\overline{\text { Control }_{. j}}\right)++\gamma_{20}\left(\text { Urbanf }_{2 j}-\overline{\text { Urbanf }_{. j}}\right)+\gamma_{30}\left(\text { Conspf }_{3 j}-\overline{\text { Conspf }_{. j}}\right) \\
& +\gamma_{40}\left(\operatorname{lnDistrain}_{4 \mathrm{j}}-{\overline{\ln \text { Distrain }_{. j}}}_{\mathrm{j}}\right)+\mu_{1 j}\left(\text { Control }_{1 j}-{\overline{\text { Control }_{. j}}}\right)+\mu_{2 j}\left(\text { Urbanf }_{2 j}-\overline{\text { Urbanf }_{. j}}\right) \\
& +\mu_{3 j}\left(\text { Conspf }_{3 j}-\overline{\text { Conspf }_{. j}}\right)+\mu_{4 j}\left(\operatorname{lnDistrain}_{4 j}-\overline{\operatorname{lnDistrain}}_{. j}\right)+\mu_{5 j} * D 1+\mu_{6 j} * D 2 \\
& +\mu_{7 j} * D 3+\mu_{8 j} * D 4+\mu_{9 j} * D 5+\mu_{10 j} * D 6+\varepsilon_{i j}+\mu_{o j}
\end{aligned}
$$

In this model, the influence of the Level 2 independent variables on the first level was used to check if the former had influenced the intercepts in the latter. In other words, this model confirms whether the Level 2 variables of the pressure of agricultural land conversion and the degree of urbanization had cross-level and direct effects on the agricultural land prices of each administrative division.

\subsection{Description of Variables}

\subsubsection{Dependent Variables}

So et al. [47] mentioned that log-linear functions are suitable for assessing nonlinear models. Zient et al. [48] highlighted that when price is treated as a dependent variable, taking its logarithmic form could reduce heterogeneity in the factor estimates. This was supported by Hill et al. [49], who agreed that the distribution of a variable is closer to normal when its logarithmic form is taken. Converting a variable in a regression model into its logarithmic form makes it more practical to measure the scale of an event or object when the variable has a positive value. In this study, the logarithmic form of the dependent variable of agricultural land price was used for empirical analysis (see Table 2).

\subsubsection{First-Level Independent Variables}

(1) Lot size control measures on farmhouse construction

With regard to lot size restrictions on farmhouse construction, the amendment of the Agricultural Development Act eased restrictions on the free trading of agricultural land by allowing natural persons to gain possession of agricultural lands and build individual or collective farmhouses, under the condition that such constructions would not have negative impacts on the agricultural production environment and the development of farming communities. Article 18 of the Agricultural Development Act states that a farmhouse can only be erected on agricultural land with a minimum lot size of 0.25 hectares $\left(2500 \mathrm{~m}^{2}\right)$. Chang and Lin [50] studied the impacts of minimum lot size control measures on agricultural land prices in Taiwan. The authors analyzed agricultural land auction profiles between 2000 and 2008 and concluded that agricultural land plots larger than 0.25 hectares have dual purposes: growing crops and erecting farmhouses. Therefore, the value of such a piece of land is the sum of its initial farming value and the value of the right to build a farmhouse. As a result, agricultural land plots larger than 0.25 hectares should be more expensive than those smaller than 0.25 hectares. In this study, lot size restrictions on farmhouse construction was set as a dummy variable, with land plots smaller than 0.25 hectares serving as a reference group, that is, land plots larger than 0.25 hectares are given a score of 1 , while those smaller than 0.25 hectares are given a score of 0 . The impacts were expected to be positive. 


\section{(2) Land use zoning}

In terms of land use zoning, Henneberry and Barrows [51] concluded that zoning regulations are reflected in land prices through capitalization. Brueckner [52] studied the Greenbelt legislation in Ontario, Canada, which aims to protect agricultural land. The results show that high-value development of suburban agricultural land with nonagricultural development restrictions had the effect of lowering the price of agricultural land with development restrictions, relative to those without such restrictions. Li [53] showed that zoning restrictions exert anticipatory influences on landlords, resulting in a significant price gap between the rental rates of agricultural and nonagricultural lands. Consequently, any increase in agricultural land price would be affected by the anticipated value of land conversion. Chicoine [1] pointed out that the convergence of agricultural and urban forces at the urban fringe affects the value of agricultural land ownership and thereby increases land prices.

In this study, based on the transaction data retrieved from the price registration system, three land zone types were established: urban agricultural zones, nonurban special agricultural zones and nonurban general agricultural zones. Nonurban general agricultural zones were used as a reference group and two dummy variables were specified. For the Urbanf variable, urban agricultural zones were specified as 1 , while the other two zones were specified as 0 . For the Conspf variable, nonurban special agricultural zones were specified as 1 , while the other two zones were specified as 0 . The impacts were expected to be positive or negative.

(3) Distance from agricultural land to railway station

In the past, mass amounts of sugarcane harvested in Pingtung County were transported predominantly by rail, which propelled the sugar industry. Drescher, Henderson and McNamara [29] suggested that urban accessibility affects agricultural land value, as the distance from an agricultural land to a highway can determine whether the residential or recreational needs of farmers are met. Huang, Miller, Sherrick and Go'mez [7], taking nonproduction factors into account, examined the impacts that the distance from an agricultural land to urban areas had on land prices. Based on the theories of von Thunen, Livanis et al., those authors [28] demonstrated that urban sprawl reduces the cost of traveling to agricultural land close to urban areas, and that such land is often converted for high-value agricultural developments. The empirical results of Sheng et al. [54] showed that a $1 \%$ reduction in transportation costs between farms and ports will increase land prices by $0.33 \%$. However, no significant differences were found between rail and road transportation. This study used the logarithmic form of the distance between an agricultural land and the railway station of each administrative division (or the nearest railway station). The coefficient of the distance to a railway station was expected to have a negative value.

\section{(4) Year of agricultural land transaction}

Huang et al. [7] stated that the factors influencing agricultural land prices in Illinois change with time and space. Tsoodle, Golden and Featherstone [13] examined whether transaction prices vary with time trends by specifying a continuous number for each year to compensate for the impacts of time on transaction prices. This study collected land transaction data from 2012 to 2018. The year 2012 served as a reference group and six dummy variables were specified, represented by Dk, $k 1, \ldots, 6$. The coefficient was expected to have a positive or negative value.

\subsubsection{Second-Level Independent Variables}

(1) Pressure of agricultural land conversion

Skog and Steinnes [55] asserted that urban sprawl is the main driving force behind agricultural land conversion. Kuo [2] pointed out that converted agricultural land plots are usually located in plains or are desirable locations for nonagricultural purposes such as residential, commercial or 
industrial buildings, and public infrastructure. Myrna, Odening and Ritter [56] argued that Germany's implementation of a renewable energy program had increased land prices by $179.7 \%$ due to the possibility of wind turbine installation. In comparison with land parcels without wind turbines, the prices of neighboring parcels increased by $56.9 \%$, and were $32.2 \%$ more expensive than land parcels suitable for installing wind turbines. This finding indicates that the need for industrial development will affect agricultural land prices and land conversion.

Nelson and Schumaker [26] utilized agricultural land transaction data and included variables such as agricultural land transaction price, transacted acreage and net returns. Their empirical evidence showed the impacts of agricultural land conversion on land prices. Huang [57] employed a negative exponential model and took the quotient of the total population of a region to the total agricultural land size as an indicator of the pressure of agricultural land conversion. The empirical results indicated that the difference between the price return of an agricultural land and its market value increases with decreasing distance between agricultural land and city center. Therefore, the pressure of agricultural land conversion affects land prices.

In this study, the quotient of the total population of an administrative division to the total agricultural land size was employed as an indicator of the pressure of agricultural land conversion. Pressure of agricultural land conversion index $=$ (mean population of an administrative division ${ }^{1}$ /agricultural land size of the division (hectares) $) * 100 \%$. The logarithmic form of the quotient was used during empirical analysis. The coefficient was expected to have a positive value, that is, the greater the pressure of agricultural land conversion, the larger its impact on land prices.

\section{(2) Degree of urbanization}

Capozza and Helsly [58] analyzed several components of land value to explain the value of expected future rent increases derived from urban population growth. Peng and Tsai [59] argued that indicators of socioeconomic development such as household income, total population and population density in urban and rural townships have impacts on land prices. Drescher, Henderson and McNamara [30] agreed that urban and rural township populations affect agricultural land prices. Borchers, Ifft and Kuethe [25] categorized nonagricultural land factors, such as population density, into population and urban influence. In summary, the needs of rising populations will affect land use sizes and, subsequently, agricultural land prices $[7,14,25]$. In this study, population density was treated as a continuous variable that reflects the degree of urbanization. Degree of urbanization $=$ mean population of an administrative division/agricultural land size of the division $\left(\mathrm{m}^{2}\right)$. The logarithmic form of the quotient was used during empirical analysis. The coefficient was expected to have a positive value, that is, the higher the degree of urbanization, the higher the expected agricultural land price.

\section{Data Sources and Descriptive Statistics of the Sample}

\subsection{Introduction to Pingtung County}

Pingtung County is a major hub for agricultural developments in Taiwan. Its abundant and diverse agricultural, livestock and fishery industries are of high economic value. The main industries of Pingtung County ${ }^{2}$ are agriculture and fisheries; the county government has largely promoted tourism in recent years. Pingtung County has an area of $2700 \mathrm{~km}^{2}$ covering 33 cities and urban and rural townships. The mean population from 2012 to 2018 was 841,576; the population in 2018 was 825,406. Industries in the county include primary industries (agriculture, fishery and forestry); secondary industries (with the food production industry accounting for a major proportion, followed by metal products

Calculated by taking the mean population from 2012 to 2018.

2 Data from Wikipedia https://zh.wikipedia.org/zh-tw/\%E5\%B1\%8F\%E6\%9D\%B1\%E7\%B8\%A3. Last accessed on 2 November 2019. 
manufacturing, transportation equipment manufacturing and repairing, and nonmetallic mineral products manufacturing; there are three major industrial zones and an agricultural biotechnology park); and tertiary industries (a majority of which are commerce, followed by finance and then postal and telecommunications). The overall population of the county is declining. As a result of urban sprawl, where agricultural land is being converted into industrial zones and residential areas, agricultural land prices in the county have been on the rise. Moreover, since the Agricultural Development Act has eased the restrictions on purchasing agricultural land, the anticipatory psychological effects of this are conveyed through investment and development needs, as well as diverse types of agricultural operations. These developments have increased the number and price of agricultural land transactions in Pingtung County over time (see Figure 1).

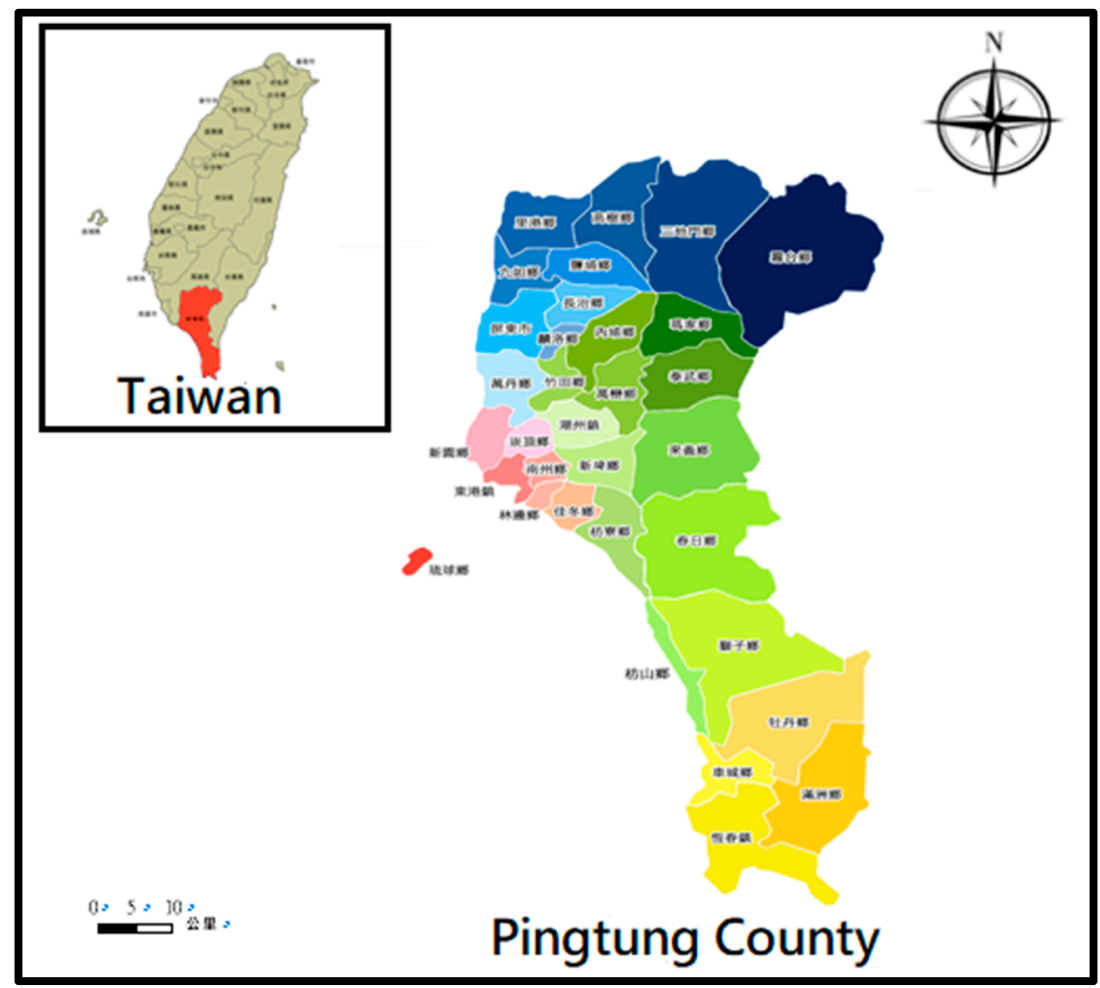

Figure 1. Map of Pingtung County.

\subsection{Data Sources}

The data in this study was acquired from two sources. The Level 1 data pertaining to agricultural land characteristics were retrieved from the actual transaction price registration system of the Ministry of the Interior. There were 15,068 pieces of Pingtung County land transaction data from 2012 to 2018 , and agricultural lands were classified in to urban agricultural zones, nonurban special agricultural zones and nonurban general agricultural zones. Pingtung County consists of 33 administrative divisions. Administrative divisions with less than 10 pieces of transaction data were omitted from the sample. The divisions were Laiyi Township (3 pieces), Chunri Township (2 pieces) and Shihzih Township (1 set). Divisions with no agricultural land-only transactions were omitted also; these were Wutai Township, Sandimen Township, Machia Township and Wutai Township. In addition, 12 pieces of data with a total transaction price of NT\$0 and 218 pieces with a unit price of NT $\$ 0$ were omitted. This leaves a total of 14,832 pieces of data encompassing 26 administrative districts in the sample.

The Level 2 data pertaining to administrative division characteristics was obtained from the Department of Budget, Accounting, and Statistics and the Department of Urban and Rural Development 
of the Pingtung County Government ${ }^{3}$. Data on the size, mean population and mean agricultural land size of each administrative division from 2012 to 2018 were used to calculate the population density (which represents the degree of urbanization) and the pressure of agricultural land conversion index.

\subsection{Descriptive Statistics of Samples}

\subsubsection{Descriptive Statistics of Level 1 Variables}

Table 3 presents the descriptive statistics of the Level 1 variables. The mean agricultural land price was NT $\$ 4,476,870$. In terms of lot size control measures on farmhouse construction, there were 8039 and 6793 transactions involving land plots smaller and greater than 0.25 hectares, which accounted for $54.2 \%$ and $45.8 \%$ of all transactions, respectively. In terms of land use zoning, there were 9674,2891 and 2267 transactions involving nonurban general agricultural zones, nonurban special agricultural zones and urban agricultural zones, which accounted for $65.2 \%, 19.5 \%$ and $15.3 \%$ of all transactions, respectively. In terms of the distance from a plot of agricultural land to the railway station of each administrative division (or the nearest railway station), the mean distance was 10,313.953 m; the standard deviation was 76,022.863 m; the maximum was 2,472,539.953 m; and the minimum was $16.935 \mathrm{~m}$. In terms of the year of transaction, 2013, 2015 and 2015 were the years with the highest number of transactions, in which 3126, 3011 and 2683 transactions occurred in each year, accounting for $21.1 \%, 20.3 \%$ and $18.1 \%$ of all transactions, respectively.

Table 3. Descriptive statistics of Level 1 variables $(n=14,832)$.

\begin{tabular}{|c|c|c|c|c|}
\hline Variable & Mean & SD & Minimum & Maximum \\
\hline $\begin{array}{l}\text { Agricultural land price } \\
\text { (in units of NT } \$ 10,000 \text { ) }\end{array}$ & 477.687 & 656.117 & 0.049 & $24,062.732$ \\
\hline \multirow[t]{2}{*}{$\begin{array}{l}\text { Distance to railway } \\
\text { station }(\mathrm{m})\end{array}$} & $10,313.953$ & $76,022.862$ & 16.93 & $2,472,539.953$ \\
\hline & Variable & Frequency (\%) & & \\
\hline \multirow{2}{*}{$\begin{array}{l}\text { Lot size control } \\
\text { measures }\end{array}$} & Larger than 0.25 hectares & $6793(45.8 \%)$ & & \\
\hline & Smaller than 0.25 hectares & $8039(54.2 \%)$ & & \\
\hline \multirow{3}{*}{ Land use zoning } & Urban agricultural zones & $2267(15.3 \%)$ & & \\
\hline & Nonurban special agricultural zones & $2891(19.5 \%)$ & & \\
\hline & Nonurban general agricultural zones & $9674(65.2 \%)$ & & \\
\hline \multirow{7}{*}{ Year of transaction } & 2012 & $1234(08.3 \%)$ & & \\
\hline & 2013 & $3126(21.1 \%)$ & & \\
\hline & 2014 & $3011(20.3 \%)$ & & \\
\hline & 2015 & $2683(18.1 \%)$ & & \\
\hline & 2016 & $2160(14.6 \%)$ & & \\
\hline & 2017 & $2493(16.8 \%)$ & & \\
\hline & 2018 & $125(0.8 \%)$ & & \\
\hline
\end{tabular}

\subsubsection{Descriptive Statistics of Level 2 Variables}

In this study, the Level 2 variables included the pressure of agricultural land conversion (calculated by taking the quotient of the mean population to the mean agricultural land size $\left(\mathrm{m}^{2}\right)$ of an administrative division) and the degree of urbanization (calculated by taking the quotient of the mean population to the mean land size $\left(\mathrm{km}^{2}\right)$ of an administrative division). The descriptive statistics are shown in Table 4. The mean pressure of agricultural land conversion was 1185.91, that is, a mean of 1186 people

3 Source: The Department of Budget, Accounting, and Statistics and the Department of Urban and Rural Development of the Pingtung County Government. https://www.pthg.gov.tw/planeab/Default.aspx. Last accessed on 2 November 2019. 
per square meter of agricultural land; the mean degree of urbanization was 721.3 , that is, a mean of 721 people per square kilometer of land.

Table 4. Descriptive statistics of Level 2 variables $(n=26)$.

\begin{tabular}{ccccc}
\hline Variable & Mean & SD & Minimum & Maximum \\
\hline Pressure of agricultural land conversion & 1185.91 & 926.79 & 94.27 & 4565.54 \\
\hline Degree of urbanization & 721.30 & 667.40 & 26.71 & 3121.92 \\
\hline
\end{tabular}

\section{Analysis of Empirical Results}

\subsection{Null Model}

The objective of the null model was to analyze whether differences exist between the mean agricultural land price in each administrative division, as well as the proportion of variance contributed by the differences between administrative divisions to the total variance of a land price.

As shown in Table 5, the fixed effects model showed that the grand mean agricultural land price $\left(\gamma_{00}\right)$ of the 26 administrative divisions in Pingtung County, as estimated through the weighted least squares method (WLS), was 14.543; the standard error was 0.125 ; the within-group variance was estimated to be 1.486 . The difference $\left(\mu_{0 j}\right)$ between the mean land price $\left(\tau_{00}\right)$ and the grand mean land price of the 26 administrative divisions (the between-group variance), as estimated through the restricted maximum likelihood method, was 0.414 , and attained a $1 \%$ level of significance. Therefore, significant differences exist in the mean land price of the administrative divisions. This shows that it is appropriate to use HLM for subsequent analysis. The proportion of between-group variances in the overall variance (i.e., the ICC of the model) was $0.218(0.414 /(0.414+1.486)=0.218)$. This shows that $21.8 \%$ of between-group variances significantly affected the mean agricultural land price, that is, $21.8 \%$ and $78.2 \%$ of agricultural land prices were affected by Level 2 and Level 1 differences, respectively.

Table 5. Summary of null model analysis results—Logarithmic form of total price.

\begin{tabular}{ccccc}
\hline Fixed Effects & Coefficient & Standard Error & t-Ratio & p-Value \\
\hline $\begin{array}{c}\text { Mean agricultural land price of an } \\
\text { administrative division } \gamma_{00}\end{array}$ & 14.543 & 0.125 & 116.158 & $0.001{ }^{* * *}$ \\
\hline Random Effects & Variance & Degree of Freedom & Chi-Square & p-Value \\
\hline Mean agricultural land price $\tau_{00}$ & 0.414 & 25 & 1833.708 & $0.001 * * *$ \\
Level 1 within-group deviance $\sigma^{2}$ & 1.486 & & \\
Number of estimated parameters & $48,093.447$ & & & \\
*** represents $\mathrm{p}<0.01 ;{ }^{* *}$ represents $\mathrm{p}<0.05 ; *$ represents $\mathrm{p}<0.1 ;$ standard errors are calculated as robust \\
standard errors.
\end{tabular}

\subsection{Intercepts-And-Slopes-As-Outcomes Regression Model}

First, using OLS, we obtained an $R^{2}$ of 0.364 and VIF values that were smaller than 10. Neter et al. [60] suggested that VIF values smaller than 10 indicate the absence of significant collinearity between independent variables. We have revised the main text to include this information. The results estimated through the intercepts-and-slopes-as-outcomes regression model are presented in Table 6. In terms of fixed effects, the estimated coefficient of the pressure of agricultural land conversion $\left(\gamma_{01}\right)$ was 0.546 , and attained a level of significance of $1 \%$. The estimated coefficient of the degree of urbanization $\left(\gamma_{02}\right)$ was 0.683 , and also attained a level of significance of $1 \%$. This shows that the pressure of agricultural land conversion and degree of urbanization have both cross-level and direct impacts on agricultural land prices. Our results corroborate those of Koomen et al. [3] and Busck et al. [4], who found that the pressure of agricultural land conversion influences agricultural 
land prices. Agricultural land prices are also associated with the degree of urbanization. This finding supports those of Pope III and Goodwin Jr [6], Huang et al. [7] and Taylor and Brester [8].

Table 6. Results of the intercepts-and-slopes-as-outcomes regression model-Natural logarithm of total price.

\begin{tabular}{|c|c|c|c|c|}
\hline Fixed Effects & Coefficient & Standard Error & t-Ratio & p-Value \\
\hline $\begin{array}{l}\text { Grand mean agricultural land price in an } \\
\text { administrative division } \gamma_{00}\end{array}$ & 14.285 & 0.120 & 118.229 & $0.001^{* * *}$ \\
\hline Pressure of agricultural land conversion (Press) $\gamma_{01}$ & 0.546 & 0.118 & 4.596 & $0.001^{* * *}$ \\
\hline Degree of urbanization (Urbanization) $\gamma_{02}$ & 0.683 & 0.159 & 4.272 & $0.001^{* * *}$ \\
\hline $\begin{array}{c}\text { Farmhouse lot size control measures (Control) } \\
\text { intercept } \gamma_{10}\end{array}$ & 1.600 & 0.060 & 26.430 & $0.001^{* * *}$ \\
\hline Zoning (Urbanf) intercept $\gamma_{20}$ & 0.100 & 0.096 & 1.042 & 0.308 \\
\hline Zoning (Conspf) intercept $\gamma_{30}$ & 0.399 & 0.081 & 4.883 & $0.001 * * *$ \\
\hline $\begin{array}{l}\text { Distance from a land to a railway station } \\
\text { (lnDistrain) intercept } \gamma_{40}\end{array}$ & 0.017 & 0.072 & 0.237 & 0.815 \\
\hline D1 intercept $\gamma_{50}$ & 0.165 & 0.068 & 2.415 & $0.024^{* *}$ \\
\hline D2 intercept $\gamma_{60}$ & 0.238 & 0.065 & 3.616 & $0.002^{* * *}$ \\
\hline D3 intercept $\gamma_{70}$ & 0.330 & 0.063 & 5.236 & $0.001^{* * *}$ \\
\hline D4 intercept $\gamma_{80}$ & 0.340 & 0.076 & 4.471 & $0.001^{* * *}$ \\
\hline D5 intercept $\gamma_{90}$ & 0.361 & 0.066 & 5.424 & $0.001^{* * *}$ \\
\hline D6 intercept $\gamma_{100}$ & 0.193 & 0.097 & 1.981 & $0.058^{*}$ \\
\hline Mean agricultural land price $\tau_{00}$ & 0.360 & 8 & 121.700 & $0.001^{* * *}$ \\
\hline Farmhouse lot size control measures (Control) $\tau_{11}$ & 0.080 & 10 & 150.688 & $0.001 * * *$ \\
\hline Zoning (Urbanf $) \tau_{22}$ & 0.250 & 10 & 43.916 & $0.001^{* * *}$ \\
\hline Zoning (Conspf) $\tau_{33}$ & 0.133 & 10 & 51.125 & $0.001^{* * *}$ \\
\hline $\begin{array}{l}\text { Distance from a land to a railway station } \\
\text { (lnDistrain) } \tau_{44}\end{array}$ & 0.116 & 10 & 57.306 & $0.001 * * *$ \\
\hline $\mathrm{D} 1 \tau_{55}$ & 0.091 & 10 & 16.592 & $0.083 *$ \\
\hline $\mathrm{D} 2 \tau_{66}$ & 0.084 & 10 & 17.905 & $0.056 *$ \\
\hline D3 $\tau_{77}$ & 0.077 & 10 & 23.406 & $0.009 * * *$ \\
\hline $\mathrm{D} 4 \tau_{88}$ & 0.114 & 10 & 26.098 & $0.004^{* * *}$ \\
\hline D5 $\tau_{99}$ & 0.084 & 10 & 24.765 & $0.006^{*}$ \\
\hline D6 $\tau_{101}$ & 0.109 & 10 & 16.607 & 0.083 \\
\hline Level 1 within-group deviance $\sigma^{2}$ & 0.911 & & & \\
\hline & $41,080.601$ & & & \\
\hline Number of estimated parameters & 67 & & & \\
\hline
\end{tabular}

${ }^{* * *}$ represents $\mathrm{p}<0.01,{ }^{* *}$ represents $\mathrm{p}<0.05,{ }^{*}$ represents $\mathrm{p}<0.1$; standard error in this table is robust standard error.

The estimated coefficient of lot size restrictions on farmhouse construction was $\left(\gamma_{10}\right) 1.600$, and attained a level of significance of $1 \%$. This indicates that these restrictions have elevated the price of agricultural land plots larger than 0.25 hectares by $160 \%$, relative to the price of lands smaller than 0.25 hectares. This demonstrates that lot size restrictions on farmhouse construction influence agricultural land prices. Butsic et al. [61] studied the effects of agricultural land controls on agricultural land fragmentation in Wisconsin. The authors noted that exclusive agriculture zoning (EAZ) was implemented in Wisconsin to prevent fragmentation of agricultural land. A farmhouse can be built on every 35 hectares of an EAZ parcel, and the agricultural land can be converted for residential developments. Moreover, landowners can request amendments to EAZ regulations to develop their own parcels. Lee [33] highlighted that in addition to the significant impact of natural landscapes, lot size restrictions on farmhouse construction and competition from home stay operators had also affected agricultural land prices. Consequently, farmers are unable to obtain more land for agricultural purposes, and the impacts of economies of scale cannot be determined. Therefore, lot size restrictions on farmhouse construction, natural landscapes and market competition have knock-on effects on agricultural land prices. The estimated coefficient $\left(\gamma_{20}\right)$ of urban agricultural zones (Urbanf) was 0.100 but did not attain a level of significance. This suggests that there are no significant differences between the prices of urban agricultural zones and nonurban general agricultural zones. The estimated coefficient $\left(\gamma_{30}\right)$ of nonurban special agricultural zones (Conspf) was 0.399 and attained a level of significance of $1 \%$. This shows that nonurban special agricultural zones are $39.9 \%$ more costly than nonurban general agricultural zones. The estimated coefficient $\left(\gamma_{40}\right)$ of the distance from a land to 
a railway station was 0.017 , but did not attain a level of significance. This shows that the distance from a land to a railway station did not have significant impacts on land prices. In terms of the year of transaction, the estimated coefficients all attained a $1 \%$ level of significance, with the exception of the coefficient of D6, which attained a $10 \%$ level of significance, as well as the coefficient of D1, which attained a 5\% level of significance. This demonstrates that from 2013 to 2018, transaction prices were higher than those in 2012; in each year, the price was higher by $16.5 \%, 23.8 \%, 33.0 \%, 34.0 \%, 36.1 \%$ and $19.3 \%$ respectively.

In terms of random effects, the variances of the Level 1 independent variables all attained a $1 \%$ level of significance, with the exception of D1, D2 and D6, which attained a 10\% level of significance. This shows that in Level 1, the intercepts and the variance of each independent variable differed by administrative divisions.

\section{Conclusions and Recommendations}

\subsection{Conclusions}

This study employed multilevel modeling to perform an empirical analysis on the effects of Level 1 variables pertaining to land characteristics (restrictions on farmhouse lot size, land use zoning, distance from agricultural land to a railway station and year of transaction) and Level 2 variables pertaining to administrative division characteristics (pressure of agricultural land conversion and degree of urbanization) on agricultural land prices. Previous studies have mostly employed traditional regression analysis and hedonic pricing models to empirically analyze agricultural land prices and their influencing factors. However, this results in estimation bias as the land price differences caused by the locational characteristics of different administrative divisions are often neglected.

Firstly, empirical results derived from the null model indicate significant differences between the mean agricultural land price in each administrative division. Specifically, the ratio of agricultural land prices affected by the differences in Level 2 township-related factors was $21.8 \%$, while the ratio of agricultural land prices affected by the differences in Level 1 land-related factors was $78.2 \%$. As Nickerson and Zhang [62] highlighted, land characteristic prices are significantly influenced by heterogeneity, as well as potential omitted-variable bias. Therefore, multilevel analysis is suitable for preventing bias. Next, the results of the empirical intercepts-and-slopes-as-outcomes regression model demonstrate that the pressure of agricultural land conversion and the degree of urbanization had cross-level, direct and positive impacts on the total price of agricultural land. Lot size restrictions have elevated the price of agricultural land plots larger than 0.25 hectares by $160 \%$, relative to the price of land plots smaller than 0.25 hectares. There were no significant differences between the prices of urban agricultural zones and nonurban general agricultural zones. Nonurban special agricultural zones were $39.9 \%$ more costly than nonurban general agricultural zones.

The results of our study reflect how Taiwan's past agricultural land policy had emphasized the release of agricultural land to meet the country's economic development and land needs. The loosening of agricultural land transaction restrictions in 2000 has promoted the use of agricultural land for nonagricultural purposes and opened up the agricultural land market to the influx of capital. As a result, urban fringe regions have been experiencing a large number of agricultural land transactions involving agricultural land conversions. This development trend has hastened the urbanization of agricultural land, and consequently, agricultural land prices have increased due to the increased frequency of agricultural land transactions spurred by their acquisition at high prices by developers [63]. In neighboring Vietnam, the impact of urbanization on agricultural land has encouraged the mass conversion and development of agricultural land, leading to surging agricultural land prices that have forced farmers to rely on nonagricultural economic activities to meet their basic livelihood needs [64]. Alijani, Hosseinali and Biswas [65] utilized a geographic information system (GIS) to examine the changes in agricultural land prices in Iran's Chalus County. They discovered that, with the economic structure undergoing significant changes, industry and commerce developing rapidly, the urban 
population increasing continuously and the strong demand for land among nonagricultural sectors for developmental purposes, agricultural land conversion has become a component of urban development and has contributed to the surge in agricultural land prices. Therefore, our study examined the effects of Taiwan's agricultural land policy on Pingtung County and utilized multilevel analysis to determine how the pressure of agricultural land conversion and degree of urbanization influence agricultural land prices, generating results that indicate a positive and significant influence.

The empirical results of this study highlight the decision-making thought process behind Taiwan's past agricultural land policy, that is, the policy's emphasis on releasing agricultural land to meet the country's economic development and land needs. Therefore, the loosening of this policy has led to the use of agricultural land for nonagricultural purposes and opened up the agricultural land market to an influx of capital. This was immediately followed by a large number of agricultural land transactions involving agricultural land conversions in urban fringe regions, which have hastened the urbanization of agricultural land, and consequently, elevated agricultural land prices due to the increased frequency of agricultural land transactions spurred by their acquisition at high prices by developers. Our study examined the effects of Taiwan's agricultural land policy on Pingtung County and applied multilevel analysis to examine the township administrative districts in the county. This approach was taken to determine how the pressure of agricultural land conversion and degree of urbanization influence agricultural land prices. The results of the study indicate a positive and significant influence. In other words, the use of agricultural land is closely related to the urban development environment, socio-economic conditions and even the characteristics of individual farms. This trend of agricultural land prices being driven up by the pressure of agricultural land conversion and urbanization is an irreversible one. Japan's agricultural land conversion permit system could serve as a reference for Taiwan's government with regard to balancing land use between preserving excellent agricultural land for food security and allocating land for residential, industrial and other nonagricultural purposes. In this manner, we can prevent surges in land prices by ensuring that excellent agricultural land is utilized effectively, productively and stably.

\subsection{Recommendations}

Due to the lack of individual-level data that correspond to individual agricultural land transactions registered in the actual price registration system, the data required for the characteristic factors could not be obtained from the official statistics database of each administrative division. For instance, the variables taken into account in the literature include climate and rainfall, indicators of land-use planning benefits (economic, social and environmental-related policies), agricultural development rights (agricultural value, soil quality), whether a land plot is road-adjacent, household income and provision of building use licenses, major transportation or public infrastructure developments and agricultural land rezoning. Therefore, we hope that access to empirical data can be improved for the sake of subsequent research, so as to enhance the quality of studies pertaining to agricultural land prices.

This study focused on an empirical analysis of the effects of land policy mechanisms and the administrative division in which land is located on agricultural land prices. Subsequent research should take into account the study by Kuethe et al. [66], which looked at agricultural bankers' expectations of agricultural land price changes and asset price bubbles, and employ structural equation modeling for analysis. The study by Lee, Liang and Chou [67] can also be referred to. In this study, the authors used a Markov-switching autoregressive model to examine agricultural land price surges, thriving land transactions, as well as spatial and temporal changes on agricultural land price changes.

Author Contributions: Conceptualization, C.-C.L. and Y.-L.W.; methodology, C.-C.L.; software, C.-C.L., Y.-X.C. and W.-C.Y.; validation, Y.-L.W.; formal analysis, W.-C.Y. and Y.-X.C.; investigation, C.-C.L. and Y.-L.W.; resources, W.-C.Y.; data curation, C.-M.L.; writing-original draft preparation, C.-C.L. and Y.-L.W. All authors have read and agreed to the published version of the manuscript.

Funding: This research received no external funding. 
Conflicts of Interest: The authors declare no conflict of interest.

\section{References}

1. Lin, T.C. Study on the Price of Agricultural Land Conversion on Agricultural Land Ownership Transfers and Agricultural Land Use, Technical Research Program Report for the Year 2007; Council of Agriculture, Executive Yuan: Taipei, Taiwan, 2007.

2. Chicoine, D.L. Farmland Values at the Urban Fringe: An Analysis of Sale Prices. Land Econ. 1981, 57, $353-362$. [CrossRef]

3. Kuo, T.H. Geography of Taiwan: Natural, Societal, and Spatial Images; Wu-Nan Books: Taipei, Taiwan, 2013.

4. Koomen, E.; Rietveld, P.; De Nijs, T. Modelling land-use change for spatial planning support. Ann. Reg. Sci. 2007, 42, 1-10. [CrossRef]

5. Busck, A.G.; Kristensen, S.B.P.; Præstholm, S.; Primdahl, J. Porous landscapes-The case of Greater Copenhagen. Urban For. Urban Green. 2008, 7, 145-156. [CrossRef]

6. Pope, C.A., III; Goodwin, H.L., Jr. Impacts of Consumptive Demand on Rural Land Values. Am. J. Agric. Econ. 1984, 66, 750-754. [CrossRef]

7. Huang, H.; Miller, G.Y.; Sherrick, B.J.; Gómez, M.I. Factors Influencing Illinois Farmland Values. Am. J. Agric. Econ. 2006, 88, 458-470. [CrossRef]

8. Taylor, M.R.; Brester, G.W. Noncash Income Transfers and Agricultural Land Values. Rev. Agric. Econ. 2005, 27, 526-541. [CrossRef]

9. Hox, J.J. Applied Multilevel Analysis; TT- Publikaties: Amsterdam, The Netherlands, 1995.

10. Giuliano, G.; Gordon, P.; Pan, Q.; Park, J. Accessibility and Residential Land Values: Some Tests with New Measures. Urban Stud. 2010, 47, 3103-3130. [CrossRef]

11. Zhang, Y.; Li, X.; Song, W. Determinants of cropland abandonment at the parcel, household and village levels in mountain areas of China: A multi-level analysis. Land Use Policy 2014, 41, 186-192. [CrossRef]

12. Patton, M.; McErlean, S. Spatial Effects within the Agricultural Land Market in Northern Ireland. J. Agric. Econ. 2003, 54, 35-54. [CrossRef]

13. Tsoodle, L.J.; Golden, B.B.; Featherstone, A.M. Factors Influencing Kansas Agricultural Farm Land Values. Land Econ. 2006, 82, 124-139. [CrossRef]

14. Lehn, F.; Bahrs, E. Analysis of factors influencing standard farmland values with regard to stronger interventions in the German farmland market. Land Use Policy 2018, 73, 138-146. [CrossRef]

15. Gardner, K.; Barrows, R. The Impact of Soil Conservation Investments on Land Prices. Am. J. Agric. Econ. 1985, 67, 943-947. [CrossRef]

16. Maddison, D. A hedonic analysis of agricultural land prices in England and Wales. Eur. Rev. Agric. Econ. 2000, 27, 519-532. [CrossRef]

17. Maddison, D. A Spatio-temporal Model of Farmland Values. J. Agric. Econ. 2009, 60, 171-189. [CrossRef]

18. Palmquist, R.B.; Danielson, L.E. A Hedonic Study of the Effects of Erosion Control and Drainage on Farmland Values. Am. J. Agric. Econ. 1989, 71, 55-62. [CrossRef]

19. Faux, J.; Perry, G.M. Estimating Irrigation Water Value Using Hedonic Price Analysis: A Case Study in Malheur County, Oregon. Land Econ. 1999, 75, 440-452. [CrossRef]

20. Xu, F.; Mittelhammer, R.C.; Barkley, P.W. Measuring the Contributions of Site Characteristics to the Value of Agricultural Land. Land Econ. 1993, 69, 356-369. [CrossRef]

21. Donoso, G.; Vicente, G. A Hedonic Price Model of Argentinean Land Prices. Int. J. Agric. Nat. Res. 2001, 28, 73-81. [CrossRef]

22. Troncoso, J.L.; Aguirre, M.; Manríquez, P.; Labarra, V.; Ormazábal, Y. Influence of physical attributes on the price of land: The case of the Province of Talca, Chile. Int. J. Agric. Nat. Res. 2010, 37, 105-112. [CrossRef]

23. Nivens, H.D.; Kastens, T.L.; Dhuyvetter, K.C.; Featherstone, A.M. Using Satellie Imagery in Predicting Kansas Farmland Values. J. Agric. Res. Econ. 2002, 27, 464-480.

24. Sklenicka, P.; Molnarova, K.; Pixova, K.C.; Salek, M.E. Factors affecting farmland prices in the Czech Republic. Land Use Policy 2013, 30, 130-136. [CrossRef]

25. Borchers, A.M.; Ifft, J.; Kuethe, T. Linking the Price of Agricultural Land to Use Values and Amenities. Am. J. Agric. Econ. 2014, 96, 1307-1320. [CrossRef] 
26. Nelson, J.R.; Schumaker, S. Utilization of Income Multipliers to Evaluate Development Pressures on Farmland in Canyon County, Idaho; Department of Agricultural Economics and Rural Sociology, University of Idaho: Moscow, ID, USA, 2001.

27. Umanailo, R.; Nawawi, M.; Umanailo, M.C.B.; Malik, S.; Hentihu, I. Conversion of Farmland Namlea Subdistrict. Int. J. Sci. Technol. Res. 2019, 8, 1861-1864.

28. Livanis, G.; Moss, C.B.; Breneman, V.E.; Nehring, R.F. Urban Sprawl and Farmland Prices. Am. J. Agric. Econ. 2006, 88, 915-929. [CrossRef]

29. Delbecq, B.A.; Kuethe, T.H.; Borchers, A.M. Identifying the Extent of the Urban Fringe and Its Impact on Agricultural Land Values. Land Econ. 2014, 90, 587-600. [CrossRef]

30. Drescher, K.; Henderson, J.; McNamara, K. Farmland Prices Determinants. In Proceedings of the American Agricultural Economics Association Annual Meeting, Chicago, IL, USA, 5-8 August 2001.

31. Huang, Y.-S. Locality Analysis on Farm Land Prices in Taiwan. Master's Thesis, National Chung-Hsing University Department of Soil and Environmental Sciences, Taichung City, Taiwan, 2012.

32. Peerzado, M.B.; Magsi, H.; Sheikh, M.J. Land use conflicts and urban sprawl: Conversion of agriculture lands into urbanization in Hyderabad, Pakistan. J. Saudi Soc. Agric. Sci. 2019, 18, 423-428. [CrossRef]

33. Lee, J.-C. How Natural Landscape and Regulation of Farmland Affect Farmland Price-The Case of Hualien County. Master's Thesis, National Cheng Chi University Graduate Institute of Land Economics, Hualien County, Taiwan, 2015.

34. Bastian, C.T.; McLeod, D.M.; Germino, M.J.; Reiners, W.A.; Blasko, B.J. Environmental amenities and agricultural land values: A hedonic model using geographic information systems data. Ecol. Econ. 2002, 40, 337-349. [CrossRef]

35. Kostov, P. A Spatial Quantile Regression Hedonic Model of Agricultural Land Prices. Spat. Econ. Anal. 2009, 4, 53-72. [CrossRef]

36. Ready, R.C.; Abdalla, C.W. The Amenity and Disamenity Impacts of Agriculture: Estimates from a Hedonic Pricing Model. Am. J. Agric. Econ. 2005, 87, 314-326. [CrossRef]

37. Chatzopoulos, T.; Lippert, C. Adaptation and Climate Change Impacts: A Structural Ricardian Analysis of Farm Types in Germany. J. Agric. Econ. 2015, 66, 537-554. [CrossRef]

38. Moellering, H.; Tobler, W. Geographical Variances. Geogr. Anal. 2010, 4, 34-50. [CrossRef]

39. Lee, C.C.; Ton, T.C. Multilevel Analysis of a Housing Hedonic Price Model. Taiwan Econ. Rev. 2010, 38, 289-325.

40. Antipova, A.; Wang, F.; Wilmot, C. Urban Land Uses, Socio-demographic Attributes and Commuting: A Multilevel Modeling Approach. Appl. Geogr. 2011, 31, 1010-1018. [CrossRef]

41. Hofmann, D. An Overview of the Logic and Rationale of Hierarchical Linear Models. J. Manag. 1997, 23, 723-744. [CrossRef]

42. Brown, K.; Uyar, B. A Hierarchical Linear Model Approach for Assessing the Effects of House and Neighborhood Characteristics on Housing Prices. J. Real Estate Pract. Educ. 2004, 7, 15-24. [CrossRef]

43. Kreft, L.G.; de Leeuw, J. Introducing Multilevel Modeling; SAGE Publications Inc.: London, UK, 1998.

44. Raudenbush, S.W.; Bryk, A.S. Hierarchical Linear Models: Applications and Data Analysis Methods; SAGE Publications Inc.: London, UK, 2002.

45. McGraw, K.O.; Wong, S.P. Forming Inferences About Some Intraclass Correlation Coefficients. Psychol. Methods 1996, 1, 30-46. [CrossRef]

46. Tabachnick, B.G.; Fidell, L.S. Using Multivariate Statistics, 4th ed.; Allyn and Bacon: Needham Heights, MA, USA, 2001.

47. So, H.; Tse, R.; Ganesan, S. Estimating the influence of transport on house prices: Evidence from Hong Kong. J. Prop. Valuat. Investig. 1997, 15, 40-47. [CrossRef]

48. Zient, J.; Zient, E.N.; Sirmanas, G.S. Determinants of House Prices: A Quantile Regression Aggregation Bias. J. Real Estate Fin. Econ. 2008, 37, 317-333.

49. Hill, R.C.; Griffiths, W.E.; Lim, G.C. Principles of Econometrics, 4th ed.; Wiley: Hoboken, NJ, USA, 2013.

50. Chang, H.-H.; Lin, T.-C. Does the Minimum Lot Size Program Affect Farmland Values? Empirical Evidence Using Administrative Data and Regression Discontinuity Design in Taiwan. Am. J. Agric. Econ. 2015, 98, 785-801. [CrossRef]

51. Henneberry, D.M.; Barrows, R.L. Capitalization of Exclusive Agricultural Zoning into Farmland Prices. Land Econ. 1990, 66, 249-258. [CrossRef] 
52. Brueckner, J.K. Growth Controls and Land Values in an Open City. Land Econ. 1990, 66, 237-248. [CrossRef]

53. Li, J.Y. The Influence of Land Use Control on Land Prices. Master's Thesis, National Taiwan University Department of Agricultural Economics, Taipei, Taiwan, 1995.

54. Sheng, Y.; Jackson, T.; Lawson, K. Evaluating the benefits from transport infrastructure in agriculture: A hedonic analysis of farmland prices. Aust. J. Agric. Resour. Econ. 2018, 62, 237-255. [CrossRef]

55. Skog, K.L.; Steinnes, M. How Do Centrality, Population Growth and Urban. Land Use Policy 2016, 59, $185-196$. [CrossRef]

56. Myrna, O.; Odening, M.; Ritter, M. The Influence of Wind Energy and Biogas on Farmland Prices. Land 2019, 8, 19. [CrossRef]

57. Huang, W.-S. The Farmland Price under Urbanization Pressure-A Case Study of I-Lan County. Master's Thesis, National Taipei University, Department of Real Estate and Built Environment, Taipei, Taiwan, 2008.

58. Capozza, D.R.; Helsley, R.W. The fundamentals of land prices and urban growth. J. Urban Econ. 1989, 26, 295-306. [CrossRef]

59. Peng, C.W.; Tsai, I.C. Determinants of Homeownership Rates by Panel Data Analysis. City Plan. 2012, 37, 433-454.

60. Neter, J.; Wasserman, W.; Kutner, M.H. Applied Linear Statistical Models, 3rd ed.; Irwin: Burr Ridge, IL, USA, 1990.

61. Butsic, V.; Lewis, D.J.; Ludwig, L. An Econometric Analysis of Land Development with Endogenous Zoning. Land Econ. 2011, 87, 412-432. [CrossRef]

62. Nickerson, C.J.; Zhang, W. Modeling the Determinants of Farmland Values in the United States. Oxf. Handb. Land Econ. 2014.

63. Chang, H.S.; Chen, T.L.; Chen, P.C. Explore the Spatial Relationship between Farmland Use Changes and Farmland Transactions. J. Archit. Plan. 2013, 14, 167-182.

64. Lodder, E. Pressure on Land in Peri-urban Vietnam: The Impact of Agricultural Land Conversion and the Need for Livelihood Diversification in Thuy Duong Commune. Master's Thesis, Utrecht University Repository, Utrecht, The Netherlands, 2012.

65. Alijani, Z.; Hosseinali, F.; Biswas, A. Spatio-temporal evolution of agricultural land use change drivers: A case study from Chalous region, Iran. J. Environ. Manag. 2020, 262, 110326. [CrossRef]

66. Kuethe, T.H.; Oppedahl, D.; Hubbs, T. Agricultural Bankders' Expectations of Farmland Price Chandges and Asset Price Bubbles. In Proceedings of the 165. EAAE Seminar 'Agricultural Land Markets-Recent Developments, Efficiency and Regulation' Humboldt-Universität zu Berlin, Berlin, Germany, 4-5 April 2019.

67. Lee, C.-C.; Liang, C.-M.; Chou, H.-J. Identifying Taiwan's Real Estate Cycle Turning Points-Application of the Two-Variate Markov-Switching Autoregressive Model. J. Taiwan Land Res. 2008, 11, 155-177.

Publisher's Note: MDPI stays neutral with regard to jurisdictional claims in published maps and institutional affiliations.

(C) 2020 by the authors. Licensee MDPI, Basel, Switzerland. This article is an open access article distributed under the terms and conditions of the Creative Commons Attribution (CC BY) license (http://creativecommons.org/licenses/by/4.0/). 